\section{Non-Synchronized Nasal Intermittent Positive Pressure Ventilation (NIPPV) Versus Nasal Continuous Positive Airway Pressure (NCPAP) After Extubation in Preterm Infants with Respiratory Distress Syndrome}

\author{
Respiratuar Distres Sendromlu Preterm Bebeklerde \\ Ekstübasyon Sonrası Non-Senkronize Nazal Intermitan \\ Pozitif Basınçlı Ventilasyon (NIPPV) ile Nazal Sürekli \\ Pozitif Hava Yolu Basıncının (NCPAP) Karşılaştırılması
}

\author{
Özkan İlhan $\odot$ \\ Senem Alkan Özdemir $\odot$ \\ Sinem Akbay $\odot$ \\ Berat Kanar $\odot$ \\ Şeyma Memur $\odot$ \\ Meltem Bor $\odot$ \\ Esra Arun Özer $\odot$
}

\begin{abstract}
Objective: To determine whether non-synchronized nasal intermittent positive pressure ventilation (NIPPV) reduces the rates of extubation failure, compared to nasal continuous positive airway pressure (NCPAP), in preterm infants with respiratory distress syndrome (RDS).

Method: This retrospective study included a total of 49 premature infants who were born at $<32$ gestational weeks with a birth weight of $<1.500 \mathrm{~g}$ and required intubation due to RDS. The patients were followed up with NIPPV or NCPAP after extubation. The primary outcome was extubation failure within 48 hrs of extubation, while the secondary outcome was neonatal morbidities.

Results: A total of 23 patients received NCPAP and 26 patients NIPPV following extubation. Demographic characteristics were similar in both NCPAP and NIPPV groups. Extubation failure was observed in five (21.7\%) NCPAP, and in nine (34.6\%) NIPPV patients, although any statistically significant intergroup difference was not detected $(p=0.32)$. There were no significant intergroup differences as for post-extubation atelectasis, pneumothorax. Neonatal morbidities and mortality rates. However, the incidence of patent ductus arteriosus was statistically significantly higher in the NIPPV group $(p<0.05)$. In none of the patients gastric or intestinal perforations were observed.

Conclusion: It was concluded that NIPPV is not superior to NCPAP performed in preterm infants after extubation in reducing the incidence of reintubation and respiratory morbidities, including pneumothorax and post-extubation atelectasis.
\end{abstract}

Keywords: Extubation failure, NCPAP, NIPPV, respiratory distress syndrome, preterm infants

Öz

Amaç: Bu çalışmada, respiratuar distres sendromu (RDS) tanısı ile izlenen prematüre bebeklerde ekstübasyon sonrası non-senkronize nazal intermitan pozitif basınçlı ventilasyon (NIPPV) ile nazal devamlı pozitif havayolu basıncının (NCPAP) ekstübasyon başarııızığını önlemedeki etkinliğini belirlemek amaçlanmıştır. Yöntem: Doğum sonrası RDS nedeniyle entübe olarak izlenen $<32$ gestasyonel hafta ve $<1.500 \mathrm{~g}$ doğan toplam 49 prematüre bebek çalışmaya alındı ve retrospektif olarak değerlendirildi. Hastalar ekstübasyon sonrası NIPPV veya NCPAP modlarında izlendi. Ekstübasyon sonrası ilk 48 saatte ekstübasyon başarısızlığı primer sonuç, neonatal morbiditeler ise sekonder sonuç olarak belirlendi.

Bulgular: Ekstübasyon sonrası 23 hasta NCPAP modunda, 29 hasta ise NIPPV modunda takip edildi. Her iki grup arasında demografik özellikler açısından istatistiksel olarak anlamlı fark yoktu. Ekstübasyon başarısızlığı, NCPAP ile izlenen 5 hastada (\%21,7), NIPPV ile izlenen 9 hastada $(\% 34,6)$ gözlendi, ancak istatistiksel olarak anlamlı fark belirlenmedi $(p=0,32)$. Gruplar arasında ekstübasyon sonrası atelektazi, pnömotoraks, neonatal morbiditeler ve ölüm oranları açısından anlamlı fark yoktu, ancak patent duktus arteriozus insidansI NIPPV grubunda istatiksel olarak daha yüksekti $(p<0,05)$. Gastrik veya intestinal perforasyon hastaların hiçbirinde gözlenmedi.

Sonuç: Preterm bebeklerde ekstübasyon sonrası NIPPV'nin reentübasyon insidansını ve pnömotoraks, postekstübasyon atelektazi gibi neonatal morbiditeleri azaltmada NCPAP'den üstün olmadığı sonucuna varılmıştır.

Anahtar kelimeler: Ekstübasyon başarısızlı̆ı, NCPAP, NIPPV, respiratuar distres sendromu, preterm bebek
Alındığı tarih: 31.08 .2018

Kabul tarihi: 26.12.2018 Online Yayın tarihi: 06.12.2019

Özkan İlhan Harran Üniversitesi Hastanesi, Neonatolojji Kliniği, Şanlıurfa - Türkiye ozkanilhan-83@hotmail.com ORCID: 0000-0002-6124-9796

S. Alkan Özdemir 0000-0003-0474-7120 Behçet Uz Çocuk Hastalıkları ve Cerrahisi Eğitim ve Araştırma Hastanesi, Neonatoloji Kliniği, izmir, Türkiye

S. Akbay 0000-0003-1266-320X B. Kanar 0000-0001-7886-8932 Ş. Memur 0000-0001-6099-7496 Tepecik Eğitim ve Araştırma Hastanesi, Neonatoloji Kliniği, İmir, Türkiye

M. Bor 0000-0002-4171-2149 Harran Üniversitesi Tıp Fakültesi, Neonatoloji Kliniği, Şanlıurfa, Türkiye

E. Arun Özer 0000-0003-2634-7136 Celal Bayar Ünivesitesi Tıp Fakültesi, Neonatoloji Biim Dalı, Manisa, Türkiye 


\section{INTRODUCTION}

Neonatal endotracheal intubation and ventilation are usually administered within the first days of life in preterm infants; however, they are associated with increased rates of pulmonary morbidities including subglottic stenosis, respiratory infections, ventilator-induced lung injuries, and increased risk of chronic lung diseases. There is also an increased risk of mortality or survival with neurological disability in cases of prolonged mechanical ventilation in extremely-low-birth-weight infants ${ }^{(1-3)}$. Therefore, early weaning from invasive ventilatory support should be considered to reduce morbidity and mortality rates in this population.

Nasal intermittent positive pressure ventilation (NIPPV) and nasal continuous positive airway pressure (NCPAP) have been widely used in preterm infants as a mode of noninvasive ventilation after extubation (4-6). CPAP improves $\mathrm{PaO}_{2}$, decreases airway resistance, improves obstructive apnea, and stabilizes the chest wall and reduces its distortion by increasing the functional residual capacity ${ }^{(7)}$. In two recent studies, authors declared that infants extubated to perform NCPAP compared to headbox oxygen, had reduced requirement for invasive ventilatory support and endotracheal reintubation ${ }^{(8,9)}$. Nonetheless, respiratory support with NCPAP following extubation in these infants was associated with $40 \%$ failure rates at one week ${ }^{(10)}$.

Synchronized or non-synchronized NIPPV may be applied to the infants to assist their breathing efforts; however, the use of synchronized NIPPV (SNIPPV) requires special expensive equipment that is unavailable in our hospital ${ }^{(11)}$. Therefore, in the present study, we aimed to determine and compare the effects of NCPAP and NIPPV in preterm infants after extubation on extubation failure and respiratory morbidities in our center.

\section{MATERIALS and METHODS}

\section{Study population}

This retrospective study was conducted at Level III Neonatal Intensive Care Unit of Tepecik Training and Research Hospital between January 2014 and December 2014. The study was approved by the
Ethics Committee of Tepecik Training and Research Hospital and a written informed consent was obtained from parents. The study was conducted in accordance with the principles of the Declaration of Helsinki.

A total of 49 premature infants born at $<32$ gestational weeks with a birth weight of $<1.500 \mathrm{~g}$ and required intubation due to respiratory distress syndrome (RDS) within six hours of birth were included in this study. Those with major congenital anomalies, asphyxia, congenital heart disease, cardiovascular instability, and orofacial anomalies were excluded.

\section{Study design}

In cases requiring endotracheal intubation in the delivery room, surfactant was administered (Curosurf ${ }^{\circledR}$, $200 \mathrm{mg} / \mathrm{kg}$ ) as prophylaxis. Invasive ventilation support was initiated with synchronized intermittent positive pressure ventilation (SIPPV) using a Babylog 8000 plus ventilator (Drager Medical Inc, Drager and Siemens Company, Germany). In the weaning phase, synchronized intermittent mandatory ventilation (SIMV) was administered. Repeated doses of surfactant were administered, if the infant required $\geq 0.40$ fraction of inspired oxygen $\left(\mathrm{FiO}_{2}\right)$ to maintain a target $\mathrm{O}_{2}$ saturation level of 90 to $95 \%$. All patients were administered a loading dose of $20 \mathrm{mg} / \mathrm{kg}$ caffeine citrate and a maintenance dose of $5 \mathrm{mg} / \mathrm{kg} / \mathrm{d}$ from birth until 34 weeks of gestation. The infants were considered eligible for extubation if they were maintaining $\mathrm{SpO}_{2}$ of 90 to $95 \%$ on a $\mathrm{FiO}_{2}$ of $<0.4$ and $\mathrm{PaCO}_{2}<55$ $\mathrm{mmHg}$ with following ventilatory settings;

1. For infants weighing <1000 g: mean airway pressure (MAP), $\leq 6 \mathrm{cmH}_{2} \mathrm{O}$; peak inflation pressure (PIP), $\leq 10 \mathrm{cmH}_{2} \mathrm{O}$, and the ventilatory rate of $\leq 40 / \mathrm{min}$.

2. For infants weighing $\geq 1000 \mathrm{~g}: \mathrm{MAP}, \leq 7 \mathrm{cmH}_{2} \mathrm{O}$; $\mathrm{PIP}, \leq 13 \mathrm{cmH}_{2} \mathrm{O}$, and the ventilatory rate of $\leq 30 / \mathrm{min}$.

Both CPAP and NIPPV were delivered via binasal short prong of devices using a Babylog 8000 plus ventilator. NCPAP was set at 5-6 $\mathrm{cmH}_{2} \mathrm{O}$ and NIPPV at non-synchronized mode, at a rate of 40-50 breaths/ min, inspiratory time of $0.4 \mathrm{sec}$, positive endexpiratory pressure (PEEP) of 5 to $6 \mathrm{cmH}_{2} \mathrm{O}$, PIP of 2 $\mathrm{CmH}_{2} \mathrm{O}$ above the pre-extubation PIP and a flow rate 
Ö. İlhan ve ark., Non-Synchronized Nasal Intermittent Positive Pressure Ventilation (NIPPV) Versus Nasal Continuous Positive Airway Pressure (NCPAP) After Extubation in Preterm Infants with Respiratory Distress Syndrome

of 8 to $10 \mathrm{~L} / \mathrm{min}$. The $\mathrm{FiO}_{2}$ was adjusted continuously to keep oxygen saturation measured with pulse oximetry between 90 and $95 \%$. The orogastric tube was used in both groups to avoid gastric distension. Arterial blood gas (ABG) was measured 60 min after extubation. Then, blood gas values were obtained at least once every 6-12 hrs within the first $24 \mathrm{hrs}$ after extubation and for minimal handling, as clinically indicated. The infants were weaned from noninvasive ventilation based on the following criteria: in the NIPPV group, once the infant had ventilator settings of PIP of $14 \mathrm{cmH}_{2} \mathrm{O}$, respiratory rate of $30 / \mathrm{min}, \mathrm{FiO}_{2}$ of $<0.4$ with an acceptable clinical evidence and $A B G$ values; in the NCPAP group, $\mathrm{FiO}_{2}<0.4$ with an acceptable clinical evidence and ABG values for 24 hours.

\section{Data acquisition, primary and secondary outcomes}

Clinical data including gestational age, birth weight, gender, mode of delivery, multiple pregnancies, use of antenatal corticosteroids, need for repeated doses of surfactant, ventilator mode and settings, severity of RDS (radiographic classification) and blood gases were collected from patient files.

The primary outcome was extubation failure within 48 hrs of extubation. Extubation failure was defined as the failed noninvasive respiratory support and the need for reintubation and mechanical ventilation within $48 \mathrm{hrs}$ of extubation. Reintubation criteria were as follows: severe respiratory acidosis $\mathrm{pH}$ $<7.25, \mathrm{PaCO}_{2}>60 \mathrm{mmHg}$ ); $\mathrm{SpO}_{2}$ of $<90 \%$ with $\mathrm{FiO}_{2}$ of $\geq 60 \%$, recurrent apnea (cessation of breathing for $>20$ seconds or $>10$ seconds if associated with cyanosis and/or bradycardia with a heart rate $<100$ bpm) or severe apnea requiring bag and mask ventilation, frequent episodes of desaturations $\left(\mathrm{SpO}_{2}\right.$ $\leq 85 \%$ ), which did not respond to maximum adjusting of ventilator settings.

The secondary outcomes associated with respiratory support including duration of NCPAP/NIPPV, and invasive ventilation, postextubation atelectasis (newly developed atelectasis within $48 \mathrm{hrs}$ after extubation), incidence of pneumothorax, bronchopulmonary dysplasia (BPD) defined as oxygen requirement at 36 weeks corrected for gestational age ${ }^{(12)}$, and other outcomes including intraventricular hemorrhage (IVH) grade 3 and 4, grading according to Papile et al. ${ }^{(13)}$ periventricular leukomalacia, nec- rotizing enterocolitis (NEC) according to Bell stage 2 and $3^{(14)}$, patent ductus arteriosus (PDA) confirmed by echocardiography, retinopathy of prematurity (ROP) requiring laser therapy, presence of clinical sepsis or culture-proven late-onset sepsis, duration of hospitalization, mortality and BPD/death (defined as BPD or death at $<36$ weeks of postmenstrual age) were retrieved from the medical records. Echocardiographic criteria for hemodynamically significant PDA (hsPDA) included an increased left atrial diameter compared with the aortic root (left atriumto-aortic-root ratio $\geq 1.5$ ), visualization of the patent ductus arteriosus (PDA) ( $\geq 1.5 \mathrm{~mm}$ ), and evidence of left-to-right blood flow through the open duct. hsPDA was treated with ibuprofen or paracetamol. The indication for surgical ligation of PDA included failure of medical treatment, however, none of the patients underwent surgical treatment.

\section{Statistical analysis}

Statistical data were analyzed by using the Statistical Package for the Social Sciences (SPSS) 18.0 software (SPSS Inc., Chicago, IL). Data were expressed as mean \pm standard deviation. Continuous variables were compared by using Student-t test or MannWhitney U-test. Categorical variables were analyzed by chi-square test or Fisher's exact test. A p value of $<0.05$ was accepted as statistically significant.

\section{RESULTS}

Of 49 enrolled infants, 23 received NCPAP and 26 NIPPV following extubation. The mean gestational age of the whole study group was $27.3 \pm 2.2$ weeks and the mean birth weight was $1018 \pm 253 \mathrm{~g}$. Baseline characteristics including gestational age, birth weight, gender, mode of delivery, multiple pregnancies, antenatal corticosteroid administration, and severity of RDS were comparable between the NCPAP and NIPPV groups (Table 1).

Extubation failure was observed in five (21.7\%) NCPAP and in nine (34.6\%) NIPPV patients, although it did not reach statistical significance $(p=0.32)$. The shortest and the longest extubation times for NCPAP were $24 \mathrm{hrs}$ and $336 \mathrm{hrs}$, respectively. The shortest and the longest extubation times for NIPPV were 24 hrs and $432 \mathrm{hrs}$, respectively. Duration of both nonin- 
Table 1. Demographic features of the patients.

\begin{tabular}{lccc}
\hline & $\begin{array}{c}\text { NCPAP } \\
\text { (n=23) }\end{array}$ & $\begin{array}{c}\text { NIPPV } \\
\text { (n=26) }\end{array}$ & P \\
\hline Gestational age (weeks)* & $27.8 \pm 2.1$ & $26.9 \pm 2.3$ & 0.14 \\
Birth weight (g)* & $1049.1 \pm 218$ & $992.3 \pm 281$ & 0.36 \\
Gender (male/female) & $12 / 11$ & $15 / 11$ & 0.70 \\
Type of delivery (vaginal/sectio) & $3 / 20$ & $5 / 21$ & 0.56 \\
Apgar score at 1 min* & $6.13 \pm 0.81$ & $5.84 \pm 1.15$ & 0.33 \\
Apgar score at 5 min* & $8.08 \pm 0.94$ & $7.65 \pm 1.35$ & 0.20 \\
Premature rupture of & $4(17.4)$ & $5(19.2)$ & 0.86 \\
membranes $>$ 18 $\mathrm{h}, \mathrm{n}(\%)$ & & & \\
Maternal preeclampsia, $\mathrm{n}(\%)$ & $8(34.8)$ & $9(34.6)$ & 0.99 \\
Multiple pregnancies, $\mathrm{n}(\%)$ & $4(17.3)$ & $6(23.0)$ & 0.62 \\
Complete antenatal steroid, $\mathrm{n}(\%)$ & $8(34.7)$ & $4(15.3)$ & 0.11 \\
Severe RDS (Stage 3-4), $\mathrm{n}(\%)$ & $9(39.1)$ & $7(26.3)$ & 0.36 \\
Small for gestational age, $\mathrm{n}(\%)$ & $4(17.3)$ & $2(7.6)$ & 0.30 \\
Duration of non-invasive & $275.4 \pm 241.5$ & $390.4 \pm 315.1$ & 0.14 \\
ventilation (h)* & & & \\
Duration of intubation (h)* & $79.3 \pm 93.3$ & $107.0 \pm 119.7$ & 0.39 \\
Duration of hospitalization (day)* & $68.9 \pm 29.9$ & $60.8 \pm 34.0$ & 0.30 \\
& & & \\
\hline
\end{tabular}

*Data are presented as mean \pm standard deviation. NIPPV: Nasal intermittent positive pressure ventilation; NCPAP: Nasal continuous positive airway pressure. RDS: Respiratory distress syndrome

Table 3. Subgroup analyses between study groups.
Table 2. Comparison of neonatal outcomes between study groups.

\begin{tabular}{lccc}
\hline & $\begin{array}{c}\text { NCPAP } \\
\text { (n=23) }\end{array}$ & $\begin{array}{c}\text { NIPPV } \\
(\mathbf{n = 2 6 )}\end{array}$ & P \\
\hline Extubation failure, n (\%) & $5 / 23$ & $9 / 26$ & 0.32 \\
Intraventricular hemorrhage, grade > 2, n (\%) & $6 / 23$ & $7 / 26$ & 0.94 \\
Periventricular leukomalacia, n (\%) & $1 / 22$ & $2 / 23$ & 0.10 \\
HS patent ductus arteriosus*, n (\%) & $7 / 23$ & $16 / 25$ & 0.01 \\
Retinopathy of prematurity, n (\%) & $5 / 22$ & $5 / 21$ & 0.25 \\
Necrotizing enterocolitis, n (\%) & $3 / 23$ & $2 / 25$ & 0.91 \\
Bronchopulmonary dysplasia, n (\%) & $16 / 22$ & $16 / 21$ & 0.21 \\
Bronchopulmonary dysplasia/death, n (\%) & $17 / 23$ & $20 / 26$ & 0.80 \\
Post-extubation atelectasis, n (\%) & $5 / 23$ & $3 / 26$ & 0.34 \\
Pneumothorax, n (\%) & $1 / 23$ & $2 / 26$ & 0.63 \\
Pneumonia, n (\%) & $8 / 23$ & $9 / 26$ & 0.99 \\
Culture proven sepsis, n (\%) & $15 / 23$ & $14 / 26$ & 0.42 \\
Mortality, n (\%) & $1 / 23$ & $6 / 26$ & 0.06 \\
& & & \\
\hline
\end{tabular}

HS: Hemodynamically significant, *: Statistically significant, NIPPV: Nasal intermittent positive pressure ventilation; NCPAP: Nasal continuous positive airway pressure.

\begin{tabular}{|c|c|c|c|}
\hline Birth weight $<1000 \mathrm{~g}$ & $\begin{array}{c}\text { NCPAP } \\
(n=9)\end{array}$ & $\begin{array}{l}\text { NIPPV } \\
(n=13)\end{array}$ & $\mathbf{P}$ \\
\hline Birth weight $(\mathrm{g})^{*}$ & $835.5 \pm 79.8$ & $757.6 \pm 106.2$ & 0.07 \\
\hline Apgar score at $1 \mathrm{~min} *$ & $5.33 \pm 0.50$ & $5.15 \pm 0.98$ & 0.62 \\
\hline Apgar score at 5 min* & $7.11 \pm 0.60$ & $6.92 \pm 1.38$ & 0.70 \\
\hline Premature rupture of membranes $>18 \mathrm{~h}, \mathrm{n}(\%)$ & $2(22.2)$ & $3(23.1)$ & $>0.99$ \\
\hline Maternal preeclampsia, n (\%) & $3(33.3)$ & $5(38.5)$ & 0.80 \\
\hline Extubation failure, $\mathrm{n}(\%)$ & $4(44.4)$ & $9(69.2)$ & 0.24 \\
\hline Duration of non-invasive ventilation $(\mathrm{h})^{*}$ & $413.3 \pm 302.5$ & $522.4 \pm 368.9$ & 0.47 \\
\hline Duration of intubation $(\mathrm{h})^{*}$ & $157.3 \pm 110.0$ & $182.7 \pm 130.5$ & 0.63 \\
\hline Duration of hospitalization (day)* & $92.0 \pm 24.1$ & $69.0 \pm 42.1$ & 0.15 \\
\hline HS patent ductus arteriosus, $\mathrm{n}(\%)$ & $3(33.3)$ & $9(69.2)$ & 0.09 \\
\hline Bronchopulmonary dysplasia, n (\%) & $9 / 9$ & $10 / 13$ & 0.24 \\
\hline Birth weight $\geq 1000 \mathrm{~g}$ & $\begin{array}{l}\text { NCPAP } \\
(n=14)\end{array}$ & $\begin{array}{l}\text { NIPPV } \\
(n=13)\end{array}$ & $\mathbf{P}$ \\
\hline Birth weight $(g)^{*}$ & $1186.4 \pm 158.7$ & $1226.9 \pm 186.9$ & 0.54 \\
\hline Apgar score at $1 \mathrm{~min} *$ & $6.64 \pm 0.49$ & $6.53 \pm 0.87$ & 0.70 \\
\hline Apgar score at 5 min* & $8.71 \pm 0.46$ & $8.38 \pm 0.86$ & 0.22 \\
\hline Premature rupture of membranes $>18 \mathrm{~h}, \mathrm{n}(\%)$ & $2(14.3)$ & $2(15.4)$ & $>0.99$ \\
\hline Maternal preeclampsia, n (\%) & $5(35.7)$ & $4(30.8)$ & 0.78 \\
\hline Extubation failure, $\mathrm{n}(\%)$ & $1(7.1)$ & 0 & $>0.99$ \\
\hline Duration of non-invasive ventilation $(h)^{*}$ & $186.8 \pm 144.0$ & $258.4 \pm 181.7$ & 0.26 \\
\hline Duration of intubation $(\mathrm{h})^{*}$ & $29.1 \pm 19.2$ & $31.3 \pm 20.5$ & 0.77 \\
\hline Duration of hospitalization (day)* & $54.1 \pm 23.4$ & $52.6 \pm 22.0$ & 0.87 \\
\hline HS patent ductus arteriosus, $\mathrm{n}(\%)$ & $4 / 14$ & $7 / 12$ & 0.17 \\
\hline Bronchopulmonary dysplasia, $\mathrm{n}(\%)$ & $7 / 13$ & $6 / 11$ & 0.79 \\
\hline
\end{tabular}

${ }^{*}$ Data are presented as mean \pm standard deviation. HS: Hemodynamically significant, NIPPV: Nasal intermittent positive pressure ventilation; NCPAP: Nasal continuous positive airway pressure. 
Ö. İlhan ve ark., Non-Synchronized Nasal Intermittent Positive Pressure Ventilation (NIPPV) Versus Nasal Continuous Positive Airway Pressure (NCPAP) After Extubation in Preterm Infants with Respiratory Distress Syndrome

vasive and invasive ventilation was longer in the NIPPV group (390 hrs and $107 \mathrm{hrs}$, respectively) than the NCPAP group ( 275 hrs and 79 hrs, respectively); however, any statistically significant intergroup difference was not found $(p=0.14$ and $p=0.39$; respectively). There were no significant differences in the rate of respiratory morbidities including pneumothorax, post-extubation atelectasis, and BPD between the groups ( $p=0.63, p=0.34$ and $p=0.21$; respectively). In addition, there was no statistically significant intergroup difference in the rate of mortality and BPD/death. Both groups were also comparable in terms of the incidence of IVH, PVL, NEC, ROP, and sepsis ( $p=0.94$, $p=0.10, p=0.91, p=0.25$ and $p=0.42$; respectively). As some patients died before the $28^{\text {th }}$ day after birth, they could not be evaluated for BPD and ROP. However, the incidence of PDA was statistically higher in the NIPPV group, compared to the NCPAP group $(p<0.05)$ (Table 2). None of the patients had gastric or intestinal perforation during the study period.

On analysis of subgroup of patients weighing less than $1000 \mathrm{~g}$, the patients in the NIPPV group had higher birth weights than the NCPAP group, but any significant differences were not noted between the two study groups as for birth weights $(p=0.07)$. Incidence of extubation failure was higher in the NIPPV group, without significant intergroup differences $(p=0.24)$. While $92.8 \%$ of the infants with extubation failure was under $1000 \mathrm{~g}$ at birth (Table 3).

\section{DISCUSSION}

Although mechanical ventilation is the primary treatment modality for preterm infants with respiratory failure, it may cause upper airway injury, pulmonary injury, BPD, sepsis, and adverse neurodevelopmental outcomes. Therefore, attempts at extubation should be performed as early as possible ${ }^{(15-17)}$. In immature infants, weaning from mechanical ventilation is extremely difficult, since they mostly have inconsistent respiratory drive, a weak respiratory pump, and immature and damaged lungs (18). Extubation failure is associated with an increased risk for mortality, prolonged intensive care unit stay, and poor outcomes ${ }^{(19)}$. Therefore, successful extubation may provide long-term favorable outcomes in preterm infants.
Various modes of noninvasive mechanical ventilation have been used to provide respiratory support in preterms after extubation. Several studies evaluated the efficacy of NCPAP after extubation to prevent extubation failure and to decrease requirement for intubation. Most of these studies showed that NCPAP had beneficial effects on respiratory functions and the prevention of atelectasis following extubation ${ }^{(7)}$. NIPPV is a form of noninvasive ventilation which augments the beneficial effects of NCPAP by combining it with ventilatory inflations, thereby, reducing the need for endotracheal tube ventilation and reintubation ${ }^{(8,20)}$.

In our study, we could not find any statistically significant difference in the extubation failure rates between the NCPAP and NIPPV groups following extubation. In addition, there was no significant difference between the two groups in terms of the duration of noninvasive ventilation and mechanical ventilation. Our findings were not consistent with most of the studies and meta-analysis that compared NIPPV and NCPAP after extubation in preterm infants ${ }^{(11,21,22)}$. This inconsistency may be due to small sample size of our study and its being a singlecentered design, and higher incidence of hsPDA in the NIPPV group. Although there were no significant differences, the NIPPV group had lower gestational age and lower birth weight, therefore, there could be no difference between the two groups with regard to extubation failure and duration of ventilation. If we had had bigger sample size, differences for gestational age and birth weight between the study groups may have been statistically significant and we may have found difference among the groups in terms of extubation failure. In a meta-analysis by Lemyre et al. ${ }^{(21)}, 10$ studies comparing extubation of infants to NIPPV or NCPAP were evaluated. The authors showed that either non-synchronized or synchronized noninvasive ventilation reduced the incidence of extubation failure more effectively, compared to NCPAP. In another study by Kahramaner et al. ${ }^{(22)}$ on preterm infants, NIPPV showed more favorable results than NCPAP in reducing the need for reintubation within $48 \mathrm{~h}$ of extubation. Barrington et al. ${ }^{(11)}$ also compared nasal SIMV and NCPAP in infants of $<1251 \mathrm{~g}$ birth weight after $72 \mathrm{hrs}$ of extubation and found that the NCPAP group had a higher 
incidence of failed extubation than the nasal SIMV group. Consistent with our results, Jasani et al. (23) showed that, compared to NCPAP, the use of NIPPV did not reduce the need for reintubation and mechanical ventilation during the first $72 \mathrm{hrs}$ of extubation. In addition, Komatsu et al. ${ }^{(6)}$ reported that there was no statistically significant difference between the two methods of noninvasive ventilation performed after extubation.

As our hospital did not have an unit for delivery, all infants were transported with vehicles provided by Neonatal Emergency Transport Service of Izmir 112 Call Center to our neonatal intensive care unit. According to the literature, the transported infants have more severe respiratory distress over the first 72 hours of life, and there is a trend towards more severe long-term respiratory morbidity in these infants ${ }^{(24)}$. The newborns who were transported after birth have greater need for ventilatory support, and they are associated with longer duration of ventilation and hospitalization compared with those non-transported infants. Incidence of IVH, PDA, sepsis and BPD is higher in transported preterms than non-transported preterms, as well ${ }^{25}$. These unfavorable effects of transport may have contributed to failure of extubation, and may have effected our results.

Succes of extubation is also associated with preextubation ventilatory parameters including ventilatory rate, PIP, PEEP, MAP and $\mathrm{FiO}_{2}$. Spasojevic et al. (26) showed that PIP of $18.4 \mathrm{cmH}_{2} \mathrm{O}$ was better than PIP of $16.7 \mathrm{cmH}_{2} \mathrm{O}$ on preventing extubation faiure without significant difference in very-low birthweight newborns. Tapia-Rombo et al. ${ }^{(27)}$ reported that PIP should be $\geq 14 \mathrm{cmH}_{2} \mathrm{O}$ to attempt extubation in preterm infants with BPD. In a study by Wang et al. (28), it was stated that the preextubation MAP values were higher and the respiratory rates were lower in extremely low birthweight newborns who were extubated successfully compared to the ones with failed extubations. In our study, birth weights of 92.8\% of infants with extubation failure was under $1000 \mathrm{~g}$. The PIP and MAP values were lower, and ventilatory rate was higher prior to extubation in preterm infants with birth weights less than $1000 \mathrm{~g}$ compared with those more than $1000 \mathrm{~g}$. Although extubation failure in extremely low birth weight infants is associated with birth weight, we thought higher incidence of extubation failure in these infants may also be due to ventilator settings adjusted before extubation. The maternal risk factors such as hypertensive disorders and prolonged premature rupture of membranes (PPROM) may affect the infants' clinical condition. In our study, the incidence of maternal risk factors were similar to the results of other studies' ${ }^{(22,23)}$. We could not find any significant differences with regard to rates of hypertensive disorders and PPROM between the two study groups. Costa et al. ${ }^{(29)}$ showed that lower levels of Apgar score at 5 minutes are associated with extubation failure in newborn infants. But, in the present trial, 1 , and 5-minute-Apgar scores were similar between the study groups.

In the literature, gastrointestinal complications such as abdominal distension, feeding intolerance, NEC, and intestinal perforation did not differ between the neonates assigned to NIPPV or NCPAP following extubation ${ }^{(6,11,21-23)}$. Although there is a limited number of data on abdominal distension and feeding intolerance in our study, intestinal perforation was not observed in any of the infants. We also did not find any statistically significant difference in the NEC rates between the two groups. Furthermore, we did not detect significant differences in the rates of neonatal morbidities including sepsis, pneumothorax, IVH, ROP, BPD, BPD/death rates or mortality between the groups. Nonetheless, consistent with the study of Komatsu et al. ${ }^{(6)}$, the incidence of hsPDA was higher in the NIPPV group, compared to the NCPAP group in our study. hsPDA was defined as the ductus arteriosus having a diameter of $\geq 1.5 \mathrm{~mm}$ and a ratio of $\geq 1.5$ between the size of the left atrium and the diameter of the aortic root and diastolic reversal of blood flow in the aorta on portable echocardiography ${ }^{(30)}$. All of our patients with hsPDA were administered medical treatment without need for surgery. Similar rates of neonatal morbidities in both groups in our study show the safety of NIPPV. We thought that the higher incidence of PDA in the NIPPV group might be due to lower gestational age and birth weight in the NIPPV group in comparison with the NCPAP group.

Both the aforementioned studies showed that there was no significant difference in the rate of sepsis, air leak syndromes, IVH, and ROP between the 
Ö. İlhan ve ark., Non-Synchronized Nasal Intermittent Positive Pressure Ventilation (NIPPV) Versus Nasal Continuous Positive Airway Pressure (NCPAP) After Extubation in Preterm Infants with Respiratory Distress Syndrome

groups $^{(22,23)}$. In a meta-analysis including 10 studies, the authors could not demonstrate significant reduction in the rates of BPD/death between the groups, although air leaks decreased in preterms in the NIPPV group (21). Unlike our study, previous studies reported higher rates of BPD in preterms assigned to the NCPAP rather than NIPPV ${ }^{(5,11,23,30)}$. In contrast to our study, Kahramaner et al. ${ }^{(22)}$ found a statistically significantly lower incidence of mortality in the NIPPV group when compared to the NCPAP group. Several studies used SNIPPV for the initial treatment of RDS and as a mode of noninvasive ventilation following extubation ${ }^{(5,31-34)}$. Gizzi et al. ${ }^{(35)}$ reported that SNIPPV effectively reduced the incidence of desaturation, bradycardia, and central apnea episodes in preterm infants, compared to NIPPV and NCPAP. In a study by Huang et al. ${ }^{(34)}$, synchronized noninvasive ventilation improved gas exchange and reduced the respiratory effort after extubation in preterms recovering from RDS, compared to non-synchronized nasal ventilation. Dumpa et al. ${ }^{(33)}$ also evaluated SNIPPV and NIPPV for neonatal outcomes, and they could not find significant differences in the rates of PDA, IVH, PVL, ROP, NEC, and BPD/death between the two groups. The use of SNIPPV mode requires special expensive equipment which was not available in our center, therefore in the present study we used NIPPV mode.

Nonetheless, there are some limitations to this study. The study was designed retrospectively and conducted at a single center with a relatively small sample size, which might have affected the statistical power of the results. The data for gastrointestinal complications, such as feeding intolerance and abdominal distension were limited. Finally, the mode of SNIPPV may have been more appropriate than nonsynchronized NIPPV mode, if we had special equipment for synchronization.

In conclusion, our study results suggest that NIPPV is not superior to NCPAP in preterm infants after extubation in reducing the incidence of reintubation and respiratory morbidities, such as pneumothorax and post-extubation atelectasis. Further, large-scale studies are needed to evaluate the methods of noninvasive ventilation which can possibly reduce extubation failure.
Etik Kurul Onayı: T.C. Sağlık Bakanlığı İzmir İli Kuzey bölgesi Kamu Hastaneleri Birliği Genel Sekreterliği S.B.Ü. İzmir Tepecik Eğitim ve Araştırma Hastanesi Etik Kurulu onayı alınmıştır (2017/13).

Çıkar Çatışması: Yazarlar çıkar çatışması olmadığını ifade etmişlerdir.

Finansal Destek: Yazarlar bu çalışma için maddi destek alınmadığını beyan etmişlerdir.

Hasta Onamı: Hastaların bilgilendirilmiş onamı ailelerden alınmıştır.

Ethics Committee Approval: T.C. Ministry of Health İzmir Province Northern Region Public Hospitals Association General Secretariat S.B.Ü. Ethics Committee of İzmir Tepecik Training and Research Hospital was approved (2017/13).

Conflict of Interest: The authors have stated that they have no conflict of interests.

Funding: The authors declared that this study received no financial support.

Informed Consent: Informed consent of the patients was obtained from parents.

\section{REFERENCES}

1. Owen LS, Morley CJ, Davis PG. Neonatal nasal intermittent positive pressure ventilation: what do we know in 2007. Arch Dis Child Fetal Neonatal Ed. 2007;92(5):414-8. https://doi.org/10.1136/adc.2007.117614

2. Walsh MC, Morris BH, Wrage LA, et al. Extremely low birthweight neonates with protracted ventilation: mortality and 18-month neurodevelopmental outcomes. J Pediatr. 2005;146(6):798-804.

https://doi.org/10.1016/j.jpeds.2005.01.047

3. Et Laughon $\mathrm{MM}$, Langer JC, Bose CL, et al. Prediction of bronchopulmonary dysplasia by postnatal age in extremely premature infants. Am J Respir Crit Care Med. 2011;183(12):1715-22. https://doi.org/10.1164/rccm.201101-00550C

4. Friedlich P, Lecart C, Posen R, Ramicone E, Chan L, Ramanathan $R$. A randomized trial of nasopharyngeal-synchronized intermittent mandatory ventilation versus nasopharyngeal continuous positive airway pressure in very low birth weight infants after extubation. J Perinatol. 1999;19(6 Pt 1):413-8. https://www.ncbi.nlm.nih.gov/pubmed/10685270 https://doi.org/10.1038/sj.jp.7200205

5. Khalaf MN, Brodsky N, Hurley J, Bhandari V. A prospective randomized, controlled trial comparing synchronized nasal intermittent positive pressure ventilation versus nasal continuous positive airway pressure as modes of extubation. Pediatrics. 2001;108(1):13-7. https://www.ncbi.nlm.nih.gov/ pubmed/11433048. https://doi.org/10.1542/peds.108.1.13

6. Komatsu DF, Diniz EM, Ferraro AA, Ceccon ME, Vaz FA. Randomized controlled trial comparing nasal intermittent positive pressure ventilation and nasal continuous positive airway pressure in premature infants after tracheal extubation. Rev Assoc Med Bras. 2016;62(6):568-74. 
https://doi.org/10.1590/1806-9282.62.06.568

7. Bancalari E, Moral T del. Continuous positive airway pressure: early, late, or stay with synchronized intermittent mandatory ventilation? J Perinatol. 2006;26:33-7. https://doi.org/10.1038/sj.jp.7211471

8. Davis PG, Morley CJ, Owen LS. Non-invasive respiratory support of preterm neonates with respiratory distress: Continuous positive airway pressure and nasal intermittent positive pressure ventilation. Semin Fetal Neonatal Med. 2009;14(1):14-20. https://doi.org/10.1016/j.siny.2008.08.003

9. Davis PG, Henderson-Smart DJ. Nasal continuous positive airways pressure immediately after extubation for preventing morbidity in preterm infants. Cochrane Database Syst Rev. 2003;3:CD000143.

https://doi.org/10.1002/14651858.CD000143

10. Stefanescu BM, Murphy WP, Hansell BJ, Fuloria M, Morgan $\mathrm{TM}$, Aschner JL. A randomized, controlled trial comparing two different continuous positive airway pressure systems for the successful extubation of extremely low birth weight infants. Pediatrics. 2003;112(5):1031-8. https://www.ncbi. nlm.nih.gov/pubmed/14595042.

https://doi.org/10.1542/peds.112.5.1031

11. Barrington KJ, Bull D, Finer NN. Randomized trial of nasal synchronized intermittent mandatory ventilation compared with continuous positive airway pressure after extubation of very low birth weight infants. Pediatrics. 2001;107(4):63841. https://www.ncbi.nlm.nih.gov/pubmed/11335736. https://doi.org/10.1542/peds.107.4.638

12. Jobe AH, Bancalari E. Bronchopulmonary dysplasia. Am J Respir Crit Care Med. 2001;163(7):1723e9. https://doi.org/10.1164/ajrccm.163.7.2011060

13. Papile LA, Burstein J, Burstein R, Koffler H. Incidence and evolution of subependymal and intraventricular hemorrhage: a study of infants with birth weights less than $1,500 \mathrm{gm}$. J Pediatr. 1978;92(4):529-34. https://www.ncbi.nlm.nih.gov/ pubmed/305471. https://doi.org/10.1016/S0022-3476(78)80282-0

14. Bell MJ. Neonatal necrotizing enterocolitis. N Engl J Med. 1978;298(5):281e2. https://www.ncbi.nlm.nih.gov/ pubmed/619275. https://doi.org/10.1056/NEJM197802022980519

15. Donn SM, Sinha SK. Assisted ventilation and its complications. In: Martin RJ, Fanaroff AA, Walsh MC, editors. Fanaroff \& Martin's Neonatal-Perinatal Medicine, $10^{\text {th }}$ ed. Saunders: Elsevier 2015;1087-112.

16. Lemyre B, Davis PG, De Paoli AG, Kirpalani H. Nasal intermittent positive pressure ventilation (NIPPV) versus nasal continuous positive airway pressure (NCPAP) for preterm neonates after extubation (Review). Cochrane Database Syst Rev. 2014;9:CD003212. https://doi.org/10.1002/14651858.CD003212.pub2

17. Cummings JJ, Polin RA, AAP the Committee on Fetus and Newborn. Noninvasive Respiratory Support. Pediatrics. 2016;137(1):e20153758. https://doi.org/10.1542/peds.2015-3758

18. Bancalari E, Claure N. Principles of respiratory monitoring and therapy. In: Gleason CA, Devaskar SU, editors. Avery's Diseases of the Newborn, $9^{\text {th }}$ ed. Saunders: Elsevier 2012;612-30. https://doi.org/10.1016/B978-1-4377-0134-0.10045-9

19. Epstein SK, Ciubotaru RL, Wong JB. Effect of failed extubation on the outcome of mechanical ventilation. Chest. 1997;112(1):18692. https://www.ncbi.nlm.nih.gov/pubmed/9228375. https://doi.org/10.1378/chest.112.1.186

20. Bhandari V. Nasal intermittent positive pressure ventilation in the newborn: review of literature and evidence-based guidelines. J Perinatol. 2010;30(8):505-12. https://doi.org/10.1038/jp.2009.165

21. Lemyre B, Davis PG, De Paoli AG, Kirpalani H. Nasal intermittent positive pressure ventilation (NIPPV) versus nasal continuous positive airway pressure (NCPAP) for preterm neonates after extubation (Review). Cochrane Database Syst Rev. 2017;2:CD003212.
https://doi.org/10.1002/14651858.CD003212.pub3

22. Kahramaner Z, Erdemir A, Turkoglu E, Coşar H, Sutcuoglu S, Ozer EA. Unsynchronized nasal intermittent positive pressure versus nasal continuous positive airway pressure in preterm infants after extubation. J Matern Fetal Neonatal Med. 2014;27(9):926-9. https://doi.org/10.3109/14767058.2013.846316

23. Jasani B, Nanavati R, Kabra N, Rajdeo S, Bhandari V. Comparison of non-synchronized nasal intermittent positive pressure ventilation versus nasal continuous positive airway pressure as post extubation respiratory support in preterm infants with respiratory distress syndrome: a randomized controlled trial. J Matern Fetal Neonatal Med. 2016;29(10):1546-51. https://doi.org/10.3109/14767058.2015.1059809

24. Harding JE, Morton SM. Adverse effects of neonatal transport between level III centres. J Paediatr Child Health. 1993;29(2):146-9. https://www.ncbi.nlm.nih.gov/ pubmed/8489796 https://doi.org/10.1111/j.1440-1754.1993.tb00469.

25. Shlossman PA, Manley JS, Sciscione AC, Colmorgen GH. An analysis of neonatal morbidity and mortality in maternal (in utero) and neonatal transports at 24-34 weeks' gestation. Am J Perinatol. 1997;14(8):449-56. https://doi.org/10.1055/s-2007-994178

26. Spasojevic S, Doronjski A. Risk factors associated with failure of extubation in very-low-birth-weight newborns. J Matern Fetal Neonatal Med. 2018;31(3):300-4. https://doi.org/10.1080/14767058.2017.1285884

27. Tapia-Rombo CA, Hernández-Gutiérrez AL. Associated factors to extubation failure of neonates and infants with bronchopulmonary dysplasia. Rev Invest Clin. 2012;64(3):26274. https://www.ncbi.nlm.nih.gov/pubmed/23045949.

28. Wang SH, Liou JY, Chen CY, Chou HC, Hsieh WS, Tsao PN. Risk factors for extubation failure in extremely low birth weight infants. Pediatr Neonatol. 2017;58(2):145-50. https://doi.org/10.1016/j.pedneo.2016.01.006

29. Costa AC, Schettino Rde C, Ferreira C. Predictors of extubation failure and reintubation in newborn infants subjected to mechanical ventilation. Rev Bras Ter Intensiva. 2014;26(1):51-6.

https://doi.org/10.5935/0103-507X.20140008

30. Oncel MY, Yurttutan S, Erdeve O, et al. Oral paracetamol versus oral ibuprofen in the management of patent ductus arteriosus in preterm infants: a randomized controlled trial. J Pediatr. 2014;164(3):510-4.e1. https://doi.org/10.1016/j.jpeds.2013.11.008

31. Moretti C, Gizzi C, Papoff P, et al. Comparing the effects of nasal synchronized intermittent positive pressure ventilation (nSIPPV) and nasal continuous positive airway pressure (nCPAP) after extubation in very low birth weight infants. Early Hum Dev. 1999;56(2-3):167-77. https://www.ncbi.nlm. nih.gov/pubmed/10636595. https://doi.org/10.1016/S0378-3782(99)00046-8

32. Sai Sunil Kishore M, Dutta S, Kumar P. Early nasal intermittent positive pressure ventilation versus continuous positive airway pressure for respiratory distress syndrome. Acta Paediatr. 2009;98(9):1412-5. https://doi.org/10.1111/j.1651-2227.2009.01348.x

33. Dumpa V, Katz K, Northrup V, Bhandari V. SNIPPV vs NIPPV: does synchronization matter? J Perinatol. 2012;32(6):438-42. https://doi.org/10.1038/jp.2011.117

34. Huang L, Mendler MR, Waitz M, Schmid M, Hassan MA, Hummler HD. Effects of synchronization during noninvasive intermittent mandatory ventilation in preterm infants with respiratory distress syndrome immediately after extubation. Neonatology. 2015;108(2):108-14. https://doi.org/10.1159/000431074

35. Gizzi C, Montecchia F, Panetta V, et al. Is synchronised NIPPV more effective than NIPPV and NCPAP in treating apnoea of prematurity. Arch Dis Child Fetal Neonatal Ed. 2015;100(1):F17-23. https://doi.org/10.1136/archdischild-2013-305892 